\title{
In hoc fasciculo continentur
}

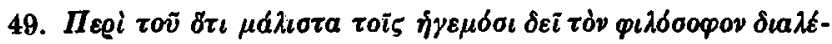
yeotac (Plan. 28) . . . . . . . . . . . . 1

Maxime cum principibus philosopho esse disserendum

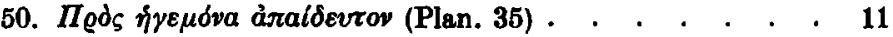

Ad principem ineruditum

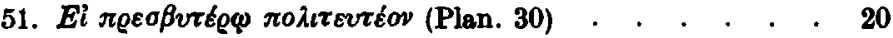
An seni sit gerenda res publica

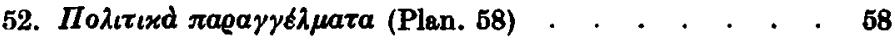
Praecepta gerendae rei publicae

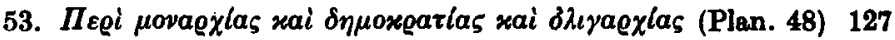
De tribus rei publicae generibus

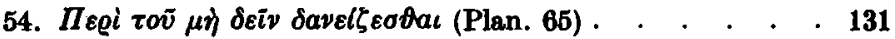
De vitando aere alieno

Addenda . . . . . . . . . . . . . . . . 143

Quisquis hune librum legit, animadvertat, ne praetereat ,,ADDITAMENTUM" signo $\square$ in margine apposito (p. 143 sqq.)

Die Deutsche Bibliothek - CIP-Einheitsaufnahme

Plutarchus:

Moralia / Plutarchus. - Nachdr.. -

Monachii ; Lipsiae : Saur

(Bibliotheca Teubneriana)

Vol. 5. Fasc. 1. / Rec, et emendavit C. Hubert.

Praefationem scripsit M. Pohlenz. -

Ed. stereotypa ed. 2 (1960). - 2001

ISBN 3-598-71682-6

(C) 2001 by K. G. Saur Verlag GmbH, München und Leipzig

Printed in Germany

Alle Rechte vorbehalten. All rights Strictly Reserved.

Jede Art der Vervielfältigung ohne Erlaubnis des Verlags ist unzulässig.

Gesamtherstellung: Strauss Offsetdruck GmbH, Mörlenbach 